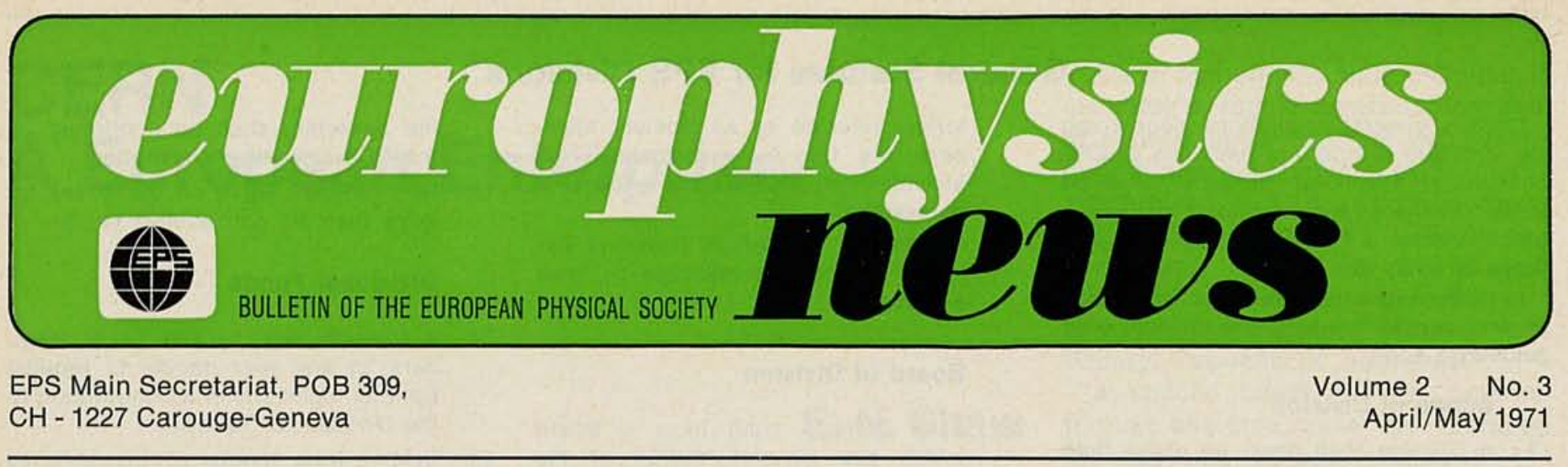

\title{
Council Session in London
}

On 18 and 19 March 1971 the Council of the European Physical Society met at Imperial Chemical House in London. The Institute of Physics (formerly the Institute of Physics and the Physical Society) acted as host and on 18 March gave a reception for the participants at their Belgrave Square headquarters. The Council meeting was attended by 30 delegates of National Societies and Academies (Members as per Article $4 \mathrm{~b}$ of the Constitution) and by three delegates of Individual Ordinary Members ( $E$. Burhop, L. Jansen and A. Kastler). Four Specialized Divisions and two Advisory Committees were also represented. To summarize the main results of the meeting :

\section{Membership}

The Physical Society of the German Democratic Republic (Physikalische Gesellschaft der Deutschen Demokratischen Republik) was accepted as Member, Article $4 b$. The total of Members, Article $4 \mathrm{~b}$, now stands at 26 . Council also accepted 194 new Individual Ordinary Members (Articles 4a and $4 \mathrm{c}$ ) which brings the total individual membership to 1699 .

The Council asked the Executive Committee to study the possibility for young physicists to become Individual Ordinary Members, Article $4 a$, at a reduced membership fee, with special regard to countries without appropriate national society or academy.

\section{Finances}

A provisional budget comparison for 1970 yields a deficit (profit-and-loss account) of Sw. Frs 30240 , as against a budgeted deficit of Sw. Frs 80260 . This more favourable result is due to higher Individual Ordinary Membership, more donations, more Associate
Members and a deficit on Europhysics News that was lower than expected. On the other hand, higher expenses than foreseen were incurred on market research on a new EPS Bulletin, the production of the Florence Inaugural Conference Proceedings and interest on the Institut Battelle loan.

Adjustment of the emergency 1971 budget (Budapest, October 1970) has proved to be necessary, both regarding income and expenditure. Firstly, a small allocation will be made to Divisions to be used at their discretion (about one Sw. Fr. per member). Secondly, the workload at the Main Secretariat has risen considerably owing to the development of activities by the Divisions and the rapid increase in Individual Ordinary and Associate Membership. A reestimate indicates that the total of Individual Ordinary Members will probably reach 2400 by October 1971 , which means that another 700 new members will join by then. The total individual membership for 1971 was budgeted at 1350 . The increase in income from Associate Membership is now estimated at Sw. Frs 26000 above the budget figure. The increased total income (about Sw. Frs 40000 ) is counter-balanced by the needs for additional staff time at the Main Secretariat to handle the larger volume of work (Sw. Frs 26 000) and by higher expenses on Europhysics News, Information Booklets and correspondence (Sw. Frs 13000 ). Council approved these provisions, and the 1971 budget is foreseen to yield a small positive balance. F. Netter and Th.A.M. van Kleef were elected as auditors for 1971.

To help with the optimization of Main Secretariat operations, Council decided to form an Administration Study Committee from among its members. This Committee on which

E. Burhop, Th.A.M. van Kleef and P. Preiswerk have agreed to serve, will first meet this May.

To facilitate the payment of fees by Individual Ordinary Members it was approved that national societies and academies should collect such fees and ensure their transfer to Geneva. Individual Members wishing to use this facility are asked to contact the appropriate body in their country.

\section{New Executive Committee}

The Council elected the following Executive Committee, to serve for the period 1 April 1971 - 31 March 1972 :

E. Rudberg

G. Bernardini

L. Jansen

N. Cindro

L. Cohen

G. Béné

L. Artsimovitch

C.M. Braams

J. Friedel

K. Ganzhorn

G. Szigeti

\section{Divisions}

At the Paris session of Council (February 1970) the Executive Committee had been asked to draft a set of rules defining the framework of operations for the EPS Specialized Divisions. After consultations with the chairmen of these Divisions the Executive Committee formulated such rules which could serve as a frame of reference for the statutes of the various Divisions, and Council accepted them with some modifications. They are given in the box overleaf.

Council emphasised the need for the board of a Division to consult its membership (i.e. Individual Ordinary Members who have joined the Division, as well as National Societies, Members Article 4b) when preparing the list of nominees for the constitution of a new board. The Executive 


\section{General Statutes for EPS Divisions}

Certain general regulations concerning the structure, scope and functions of EPS Specialized Divisions, hereafter referred to as Divisions, are contained in Constitution Articles 2.2 and $20.3 \mathrm{f}$ and By-laws Rules 29 to 31 and 39.

In conformity with these, in amplification of, and in addition to them, the following guidelines apply.

\section{Scope of Division}

1. A Division shall cover an active field of physics or a combination of related active fields. Its activities shall include :

a) Promoting in Europe the co-ordination of research activities in that field wherever possible ;

b) Organizing conferences ;

c) Furthering the exchange of research scientists and students.

\section{Membership of Division}

2. According to Articles 2.2 and $20.3 f$ of the Constitution, a Division is a part of the EPS. Consequently, members of a Division must be Ordinary Members of the EPS (Individual Ordinary Members, Constitution Article $4 a$ and $4 \mathrm{c}$ and National Societies, Academies, Laboratories or Groups, Constitution Article 4b) or Fellows. Membership of a Division shall not involve any additional fee to the Society (Bylaws Rule 39).

3. Ordinary Members and Fellows of the EPS may, but need not, be Members of one or several Specialized Divisions.

\section{Participation in Division Activities}

4. Members of adhering National Societies, Academies, Groups or Labora- tories, referred to as Society Members, are free to participate in all activities of a Division, except in decisions.

5. In addition, Specialized Divisions may invite others to participate in their activities.

\section{Board of Division}

6. Each Division shall have a Board which has general charge of the activities and other matters of direct interest to the Division.

7. Members of the Board of a Division must be Individual Ordinary Members of the EPS, Constitution Article 4a or $4 c$, Fellows, or delegates of Ordinary Members, Constitution Article $4 \mathrm{~b}$.

8. The Division Board shall consist of a Chairman, a Secretary and in addition that number of further Board Members stated in the approved statutes of the Division. Some of these other members may have assigned to them special functions, such as those of Treasurer, Vice Chairman, Vice Secretary, a.o.

Each Section ("Sub-division") to a Division shall have one representative on the Division Board.

9. The members of the Board shall be elected, each for a three-year term, by the Division members, voting at an annual meeting or by mail vote. Each Division member carries one vote; simple majority decides.

In preparing the list of nominees, the Division should consult its members.

10. The elected Board may co-opt a limited number of further members according to the Division's statutes.

11. The election of the Chairman and of the Secretary shall be confirmed by the EPS Executive Committee.

12. No one shall serve on the Board for more than six consecutive years.

\section{Divisional Funds}

13. A Division may, by vote of its members, in any year decide to request from its membership a contribution to the Division for its work.

14. Income from special contributions as well as any other ear-marked fund that a Division may acquire, remains at the disposal of the Division. The Boards of Divisions have full responsibility for ensuring that Divisions are self-supporting financially. Boards of Divisions are required to present to the Executive Committee an annual statement of accounts.

\section{Sections ("Sub-divisions")}

15. The formation of Sections of a Division shall be decided by the EPS Council upon a formal proposal by the Division Board.

\section{Interdivisional Groups}

16. Members of the EPS may create Interdivisional Groups, cutting across the physical scope of Divisions (Constitution Article 2.2 and $20.3 \mathrm{f}, \mathrm{By}$ laws Rules $29-31$ and 39).

17. The framework, general structure (Membership, Board) and operation (contributions and funds) of an Interdivisional Group are governed by the same regulations - mutatis mutandis - as those which apply for an EPS Division (1-12).
Committee was asked to examine what changes in the Constitution and the By-laws would be necessary to make members of National Societies and Academies, Article $4 b$, full members of EPS Divisions. It was put on record that Council considers it a matter of urgency to increase considerably the allocations from EPS funds to the Divisions as soon as the financial situation permits.

Council agreed to the proposed formation of a Division on Atomic Physics, with G.W. Series, Reading, as Chairman. The risk of conflicting claims of territory by the new Division was avoided thanks to prior consultations between the initiators of the proposal and the boards of several other EPS Divisions. The Division of Atomic Spectroscopy is willing to consider a merger with Atomic Physics. On the other hand, the Plasma Physics, Quantum Electronics and Physics in Astronomy Divisions prefer to maintain their separate organi- zational status. A programme outline for the new Division will appear in Europhysics News.

$A$ request had been made to form a Division of High-Energy Astrophysics, but since a Division of Physics in Astronomy had been accepted by Council at Budapest, the Executive Committee proposed that the initiators consider joining that Division.

\section{Advisory Committees}

Reports were presented from the Committee on Applied Physics and Physics in Industry and from the Conference Committee. Readers of Europhysics News are urged to complete and return the questionnaire on the relations between EPS and industry (see Europhysics News Vol. 2, No. 2, March 1971). For the Wiesbaden General Physics Conference (October 1972) only two fees for participation will be fixed, one applicable to Individual Ordinary Members and members of National Societies and Academies, Article $4 b$, and another for all other participants. The conference will be coupled with an exhibition.

A separate banking account will be opened in Geneva for Europhysics Conferences, but the Divisions retain the financial responsibility for their conferences of this type.

\section{Unesco}

It was decided to seek consultative status with Unesco, if feasible in category B. It would be helpful to obtain the support from national delegates to this end.

The next session of Council is scheduled for 19-20 October 1971 in Split, Yugoslavia.

An aerial view of the CERN Laboratories with the planned position of the $2.2 \mathrm{~km}$ ring for the Super-Protron-Synchrotron shown in white. The broken line crossing the site is the FrancoSwiss border. The ring structures visible at the bottom of the picture are the ISR tunnel on the left and the PS on the right. 